\title{
Habitat use by western purple-faced langurs Trachypithecus vetulus nestor (Colobinae) in a fragmented suburban landscape
}

\author{
R. S. Moore, K. A. I. Nekaris*, C. Eschmann \\ Anthropology Centre for Conservation Environment and Development,School of Social Sciences and Law, \\ Oxford Brookes University, Oxford OX3 0BP, UK
}

\begin{abstract}
As natural habitats around the globe disappear, humans and non-human primates become increasingly engaged in complex interactions, both peaceful and hostile. Sri Lanka's endemic western purple-faced langur Trachypithecus vetulus nestor persists in the majority of its range in complete sympatry with humans. Listed as Critically Endangered by the IUCN and one of the world's top 25 most endangered primates, their survival appears dependent on the tolerance of humans with whom they coexist. Our aims were to augment the limited information on T. v. nestor focusing on group composition and behavioural adaptations in relation to its heavily fragmented habitat. Research was carried out in Talangama Wetlands, Sri Lanka in 2007. The 5 groups varied in size from 11 to 19 individuals Monkeys regularly used fences, rooftops, power lines, and agricultural trees. Two groups of 19 and 16 individuals had home ranges of 3.06 and 2.86 ha respectively. They consumed a variety of foods including fruits, showing dietary flexibility; the fruits and leaves of Arctocarpus heterophyllus were the langurs' most frequently consumed foods. The langurs seem to be adapting to these human-modified environments. Notwithstanding, areas for concern include potentially fatal dangers when crossing between fragments, increasing human-primate conflict and intergroup conflict, and permanent genetic isolation.
\end{abstract}

KEY WORDS: Human-wildlife conflict · Commensalism · Sri Lanka · Ethnoprimatology · Infanticide • Semnopithecus

- Resale or republication not permitted without written consent of the publisher

\section{INTRODUCTION}

The effects of fragmentation on tropical ecosystems are well-documented (Marsh, 2003), but less so are the impacts of total forest loss on a species' behaviour and ecology (Manor et al. 2008, Parker et al. 2008). Many species have successfully exploited anthropogenic environments, leading to conflict (Osborne \& Parker 2003, Gusset et al. 2009) or peaceful co-existence (Colquhoun 2005, Hernandez 2008). Indeed, the number of primates coming into direct contact with humans and the problems and challenges to which this leads has led to a demand for systematic studies of how humans and primates co-exist (Sponsel et al. 2002, Riley 2006).

Many primates may be more susceptible to the adverse effects of habitat loss than other species
(Turner 1996, Marsh 2003) owing to their low reproductive potential, low dispersal capacity, and specialised habitat requirements (Cowlishaw \& Dunbar 2000, Mandujano et al. 2004). The responses to anthropogenic disturbances amongst primates vary considerably, even within groups of closely related species. Of Asia's langurs, for example, Hanuman langurs Semnopithecus sp. of the Indian subcontinent are amongst the most commensal of all primates and seem to thrive in human landscapes (Chhangani \& Mohnot 2004, Waite et al. 2007), whereas the karst-dwelling langurs Trachypithecus spp. of Indochina have all but vanished as a result of human expansion into their territories (Nadler et al. 2007, Huang et al. 2008).

Sri Lanka's Critically Endangered western purplefaced langur Trachypithecus vetulus nestor provides a 
stark example of a colobine under extreme pressure by humans (IUCN 2008). Thrice listed as one of the world's 25 most endangered primates (Rudran et al. 2009), it is restricted to a small geographic range in Sri Lanka's Wet Zone (Nekaris \& Nijman 2008); over the last $20 \mathrm{yr}$, more than $90 \%$ of its known range has been converted to residential areas, agricultural land, temples, and commercial enterprises (Rudran 2007, Stengel et al. 2009). Only $21 \%$ of the Wet Zone's dwindling forests are under protection and a mere $2 \%$ of undisturbed forest remains (Kumar et al. 1999). Consequently, the majority of the remaining population of $T$. $v$. nestor is found in unprotected areas, where they live in minute forest fragments (often $<5$ ha), with the remainder of their habitat consisting predominantly of home gardens (Dela 2007, Rudran 2007). One might suspect that langurs in this situation would be viewed as pests (cf. Boulton et al. 1996, Siex \& Struhsaker 1999). Local people, however, traditionally have tolerated this commensal species (Nahallage et al. 2008), although more recently local residents have become less forbearing of langurs that damage roof tiles, raid kitchen stores and consume cultivated plants (Nijman \& Nekaris 2010).

An understanding of how typically forest-dwelling primates, such as purple-faced langurs, cope in humanmodified habitats is becoming essential as forests diminish (Singh \& Rao 2004, Wolfe \& Fuentes 2007). Our goal was to assess group composition and habitat use with reference to high levels of human disturbance in Trachypithecus vetulus nestor living in a suburban environment in Sri Lanka, where virtually no forest remains (Parker et al. 2008). In particular, we focused on how T. v. nestor used the human-made structures in their home ranges in the context of human tolerance and langur behaviour.

\section{MATERIALS AND METHODS}

We conducted the study in the Talangama Wetlands, Kaduwella District, $10 \mathrm{~km}$ south-west of Colombo $\left(6^{\circ} 5^{\prime} 12.8^{\prime} \mathrm{N}, 79^{\circ} 5^{\prime} 0.7^{\prime} \mathrm{E}\right)$ in Sri Lanka's Wet Zone (Fig. 1). Data were collected intensively between May and July 2007, with additional data collected May to July 2006 and May 2008. The study site was chosen due to a relatively large abundance of langurs, absence of natural forests, and high levels of anthropogenic disturbance (Parker et al. 2008). The site was composed predominantly of home gardens and small rubber plantations, surrounded on 3 sides by rice paddy fields, bordered on the 4 th side by a human-made lake. Sri Lankan home gardens are traditionally composed of multi-storeyed vegetation consisting of trees, shrubs, vines, and herbs, yielding edible food sources, including leaves, fruits, flowers, and spices (Hochegger 1998). The area has a mean annual temperature of $27^{\circ} \mathrm{C}$ and a mean annual rainfall of $\sim 2500 \mathrm{~mm}$ (Ashton et al. 2001, FRGI 2004).

We followed 5 neighbouring langur groups for $6 \mathrm{~d}$ a week from $05: 00$ to $18: 30 \mathrm{~h}$ for $7 \mathrm{wk}$, to obtain data on group composition and substrate use. We studied 2 groups (A and $\mathrm{B}$ ) in detail to obtain data on day range lengths, diet, and home range size. Due to daily interactions with humans, langurs were well habituated and we were able to keep them in view almost continuously throughout the study period. We estimated age (adult, sub-adults/juveniles, and infants/new born) and sex of the individuals based on body size and pelage characters (Rudran 1973a, Rajpurohit et al. 1995).

We recorded behavioural and ranging data for Groups A and B at 15-min intervals using scan sampling (Patterson 2001). Monkeys had available to them both natural and human-made substrates, including trees, ground, rooftops, fences and walls, and wires (electric and telephone) with their posts. We also recorded all occurrences of feeding by group members in each interval, and recorded all feeding trees used throughout the study period. We measured home range size by collecting GPS waypoints at the centre of the group during 30 all-day follows. With Idrisi GIS, we used the outer perimeter of the area to calculate home range, and raster lines to calculate day range (Hanna \& Culpepper 1998).

We measured the height and diameter at breast height $(\mathrm{DBH})$ of all trees $\geq 10 \mathrm{~cm}$ in each home range; a local guide identified species, which we confirmed by

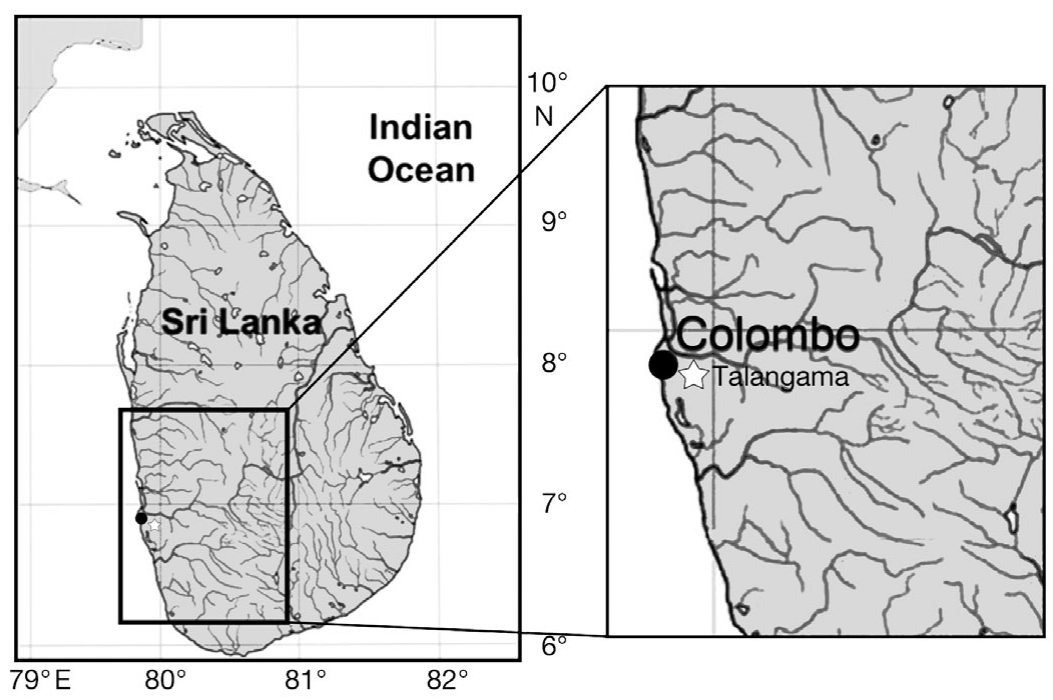

Fig 1. Study area (white star) at Talangama Wetlands in the Colombo District of Sri Lanka 
referring to Ashton et al. (1997). We quantified homerange parameters by applying biological diversity measures (species richness, Shannon-Wiener diversity index, $H^{\prime}$ ) (Fowler et al. 1998) and calculating site characteristics (basal area ha ${ }^{-1}$, tree density) (Ganzhorn 2003). Importance value indices (IVI) were derived from the summation of relative densities, frequencies and dominance (Mueller-Dombois \& Ellenberg 1974). Number of houses was counted manually and number of people was determined by interviewing local villagers. We used SPSS 14 and Excel for all statistical analyses. Means are shown with standard deviations.

\section{RESULTS}

The 5 groups (A, B, G, L, P) ranged in size from 11 to 19 individuals (Table 1 ). Of the groups, 3 contained 2 adult males. Ratios of adults to non-adults were similar in each group $\left(\chi^{2}=2.85\right.$, df $\left.=4, \mathrm{n}=72, \mathrm{p}=0.58\right)$. Four births occurred in 3 groups: 1 in Group A, 1 in L, and 2 in P. We observed 4 deaths: 2 electrocutions on power lines in the home range of Group A (Fig. 2), 1 killed by a dog as the langur travelled terrestrially, and 1 case of infanticide during an attempted take-over event between Group A and B.

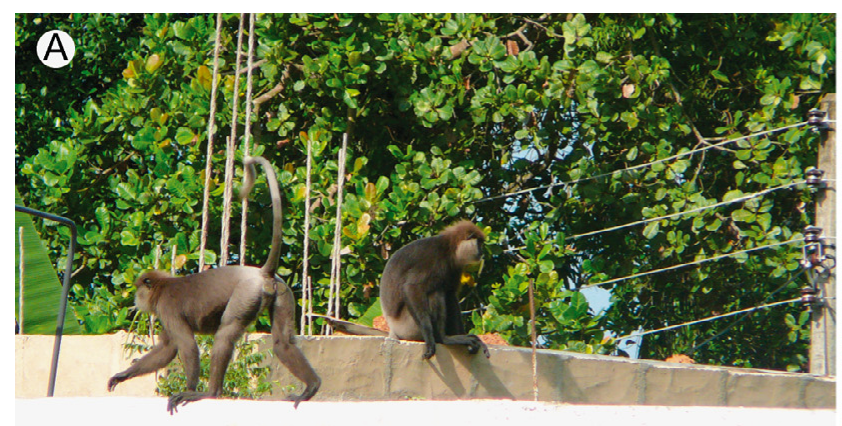

Table 1. Trachypithecus vetulus nestor. Composition of Groups A, B, G, L and P. Langurs in our study had relatively large group sizes; 3 of 5 groups unusually contained 2 adult males

\begin{tabular}{|lcccccc|}
\hline Group & $\begin{array}{c}\text { Total } \\
\text { size }\end{array}$ & $\begin{array}{c}\text { Adult } \\
\text { males }\end{array}$ & $\begin{array}{c}\text { Adult } \\
\text { females }\end{array}$ & $\begin{array}{c}\text { Sub-adults/ } \\
\text { juveniles }\end{array}$ & $\begin{array}{c}\text { Infants/ } \\
\text { newborns }\end{array}$ & $\begin{array}{c}\text { Adults: } \\
\text { immatures }\end{array}$ \\
\hline A & 19 & 1 & 8 & 5 & 5 & $1: 1.11$ \\
B & 16 & 2 & 7 & 4 & 3 & $1: 0.77$ \\
G & 11 & 2 & 3 & 5 & 1 & $1: 1.20$ \\
L & 14 & 2 & 4 & 5 & 3 & $1: 1.33$ \\
P & 12 & 1 & 4 & 3 & 4 & $1: 1.40$ \\
\hline
\end{tabular}
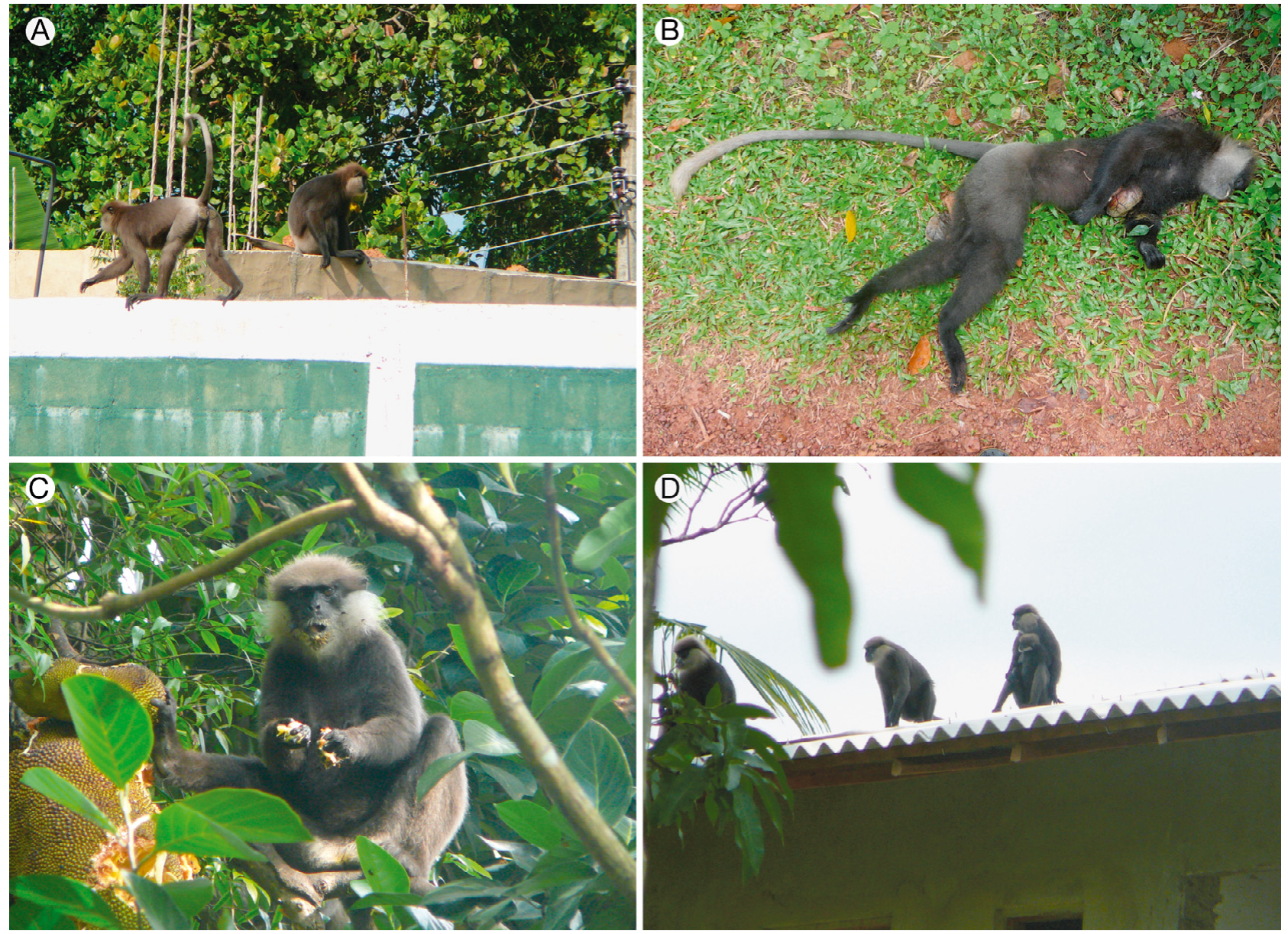

Fig 2. (A) Electric wires occurred throughout the home ranges of the 2 groups and (B) resulted in the deaths of 2 langurs during our short study. Trees were the favoured substrate of langurs, and (C) jak fruit the favoured food. (D) Roofs were the most commonly used human substrate and could accommodate many animals 
The 5 groups of langurs made use of all available natural and human-made substrates; we collected data in detail for Groups A and B (Table 2). Trees were the preferred substrate, while electricity/phone lines and the ground were rarely used. The longest distance recorded for any groups' travel on the ground was $33 \mathrm{~m}$, the shortest being $5 \mathrm{~m}$. When langurs crossed rooftops of occupied houses, the owners often chased them away or complained about damage the langurs caused. During 11 observations of Group A and 4 of Group B, humans chased the langurs out of feeding trees or off rooftops: 5 times using firecrackers, 4 times by throwing stones, 3 times by shouting, twice by chasing with sticks, once by firing a catapult.

We observed Group A feeding 312 times and Group B feeding 447 times. The 10 most common foods consumed by langurs in each group are shown in Fig. 3; 12 out of the 13 different species were also used by humans (Ashton et al. 1997). Fruit and leaves were eaten from 11 of these species; only leaves of Trema orientalis and Hevea brasiliensis were consumed. Langurs ate fruits and leaves of Artocarpus heterophyllus, the species most important to both groups. Langurs also consumed non-tree resources, including small flowering plants, berries, earth from termite mounds and discarded human food.

Mean day range length $(\mathrm{n}=7 \mathrm{~d}$ ) for Group A was 654 $\pm 111 \mathrm{~m}$, and $495 \pm 208 \mathrm{~m}$ for Group $\mathrm{B}$. The home range of both groups overlapped completely with human habitation. The home range size for Group A was 3.06 ha, and 2.86 ha for Group B, with a $4 \%$ area of overlap between them (Fig. 4). At this interface, 5 territorial battles took place lasting up to 2 min each. During these battles we heard species-typical loud calls.

Tree density in the home ranges varied from 112 trees $\mathrm{ha}^{-1}$ in Home Range A and 243 trees ha ${ }^{-1}$ in B.

Table 2. Trachypithecus vetulus nestor. Proportion of sample points during which purple-faced langurs used substrates (Group A: $\mathrm{n}=2410$; Group B: $\mathrm{n}=3131$ ). Both groups made use of all types of substrates during observations outside of the scans

\begin{tabular}{|lccccc|}
\hline Group & Trees & Roof & Ground & $\begin{array}{c}\text { Fence/ } \\
\text { wall }\end{array}$ & $\begin{array}{c}\text { Electrical } \\
\text { wires/posts }\end{array}$ \\
\hline A & 0.74 & 0.23 & 0.02 & 0.01 & - \\
B & 0.86 & 0.08 & 0.03 & 0.02 & 0.01 \\
\hline
\end{tabular}

Mean basal area was 0.13 and $0.10 \mathrm{~m}^{2}$ in A and B respectively. Species richness was similar in the 2 home ranges: in $\mathrm{A}$, we recorded a total of 61 species

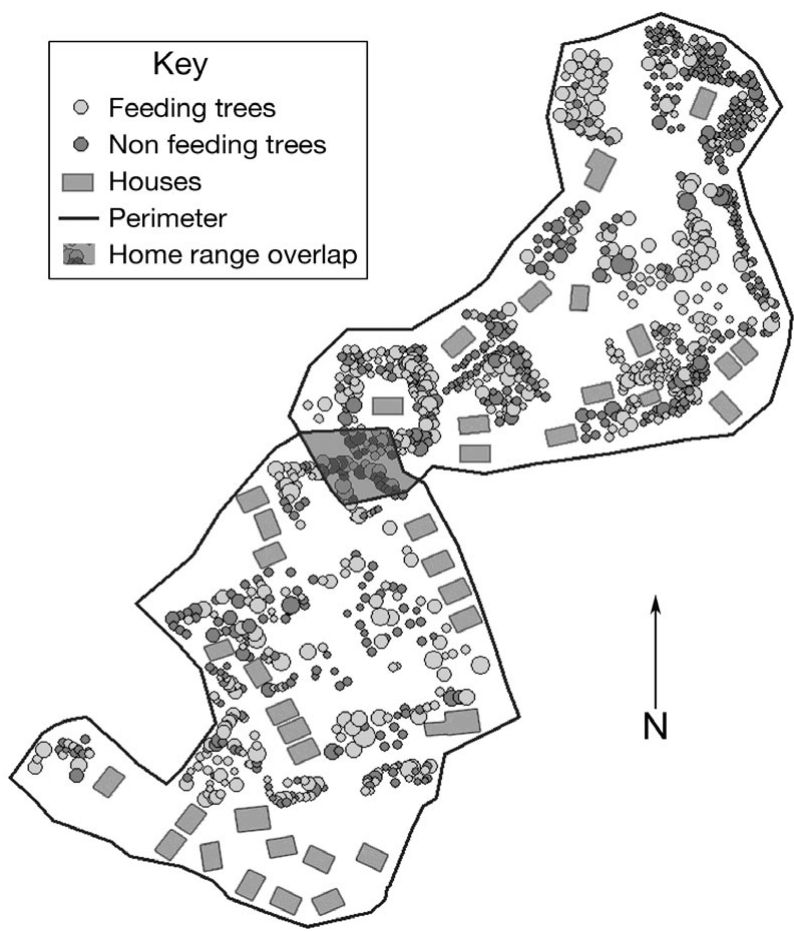

Fig 4. Home ranges for Groups A (3.06 ha) and B (2.86 ha) showing location of feeding trees and trees not used for feeding during the study period; houses and area of overlap. Circle size represents size of area covered by crown from smallest to largest: $0-2 \mathrm{~m}^{2}, 4-6 \mathrm{~m}^{2}, 6-8 \mathrm{~m}^{2}, 8-10 \mathrm{~m}^{2},>10 \mathrm{~m}^{2}$, 
representing 32 families, and in B, 69 representing 37 families. A total of 345 trees were present in Home Range A, with 177 (51\%) used as food trees by langurs. In Home Range B, 695 trees were present, of which 318 $(48 \%)$ were used as food trees. Shannon-Wiener diversity indices were also similar $\left(H^{\prime}=3.05\right.$ in $\mathrm{A}$, and $H^{\prime}=$ 3.19 in B). The top 3 tree species, as measured by the IVI, were Areca catechu (areca palm), Cocos nucifera (coconut palm) and Artocarpus heterophyllus (jak fruit) in $\mathrm{A}$, and $C$. nucifera, $A$. heterophyllus and Mangifera indica (mango) in B. With 27 versus 14 houses, and 94 versus 44 people, respectively, Home Range A had higher levels of human disturbance than B (Fig. 4).

\section{DISCUSSION}

Our study occurred in an isolated suburb and, despite its relatively short duration, we made a number of observations that can form the foundation for further studies and conservation plans for Trachypithecus vetulus nestor. Our average group size of 14 ind. is consistent with previous estimates of 1 to 21 ind. for groups of T. vetulus (Rudran 1973b, Hladik 1977, Manley 1986). Our estimate was also consistent with other studies of T. v. nestor, where group size ranged from 5 to 16 ind. (Dela 2007, Rudran 2007, Nahallage et al. 2008, Parker et al. 2008). Group sizes at the upper end of the range for all 5 groups in our study could be a consequence of the ongoing reduction in suitable habitat in Talangama, forcing groups to incorporate larger numbers of individuals into reduced available space (Bishop et al. 1981).

A possible repercussion of habitat shortage is that 3 of the 5 groups studied contained 2 adult males. Typically, the social organisation of mixed-sexed groups in Trachypithecus vetulus is the one-male unit (OMU) (Manley 1986, Kirkpatrick 2007). Males at the advent of sexual maturity leave the natal group to infiltrate OMUs by means of a violent take-over procedure, or join all-male groups known as 'wanderers' (Manley 1986, Newton \& Dunbar 1994). Whilst the occurrence of 2-male groups in this OMU-style formation has been documented in colobines before, it is uncommon (Newton 1987, Dela 2004, Kirkpatrick 2007). It is possible that the extra males were in the process of leaving the natal group and presented a temporary demographic arrangement (Sterck \& van Hooff 2000). With limited available habitat, however, emigration for these males may not be an option, as the formation of wanderer groups would be restricted and competition from alpha males in other OMUs would increase (Rudran 1973b). The presence of another adult male in a group could be beneficial to survival and fitness, such as increased predator protection, as a deterrent against infanticide and by providing extra support in inter-group disputes over territory (Bishop et al. 1981, Kirkpatrick 2007). Observation of a case of infanticide and 5 inter-group battles during this study adds weight to this concept.

Trachypithecus vetulus nestor is adapted to an arboreal lifestyle, and use of trees as the main substrate within a home range would be expected. Although descent to the ground has been reported as uncommon (Roonwal \& Mohnot 1977), in the present study and other recent studies, T. v. nestor used the ground regularly (Rudran 2007, Nekaris \& de Silva Wijeyeratne 2009). The fact that the number of natural arboreal pathways has declined forces T. v. nestor to capitalise on human-made structures and open ground as a means to travel within their territory (Dela 2004, Nekaris \& de Silva Wijeyeratne 2009). In Talangama, T. v. nestor actively used all available substrates. The isolation of trees used as sleep sites and for foraging resulted in the langurs having to find alternative means to access this preferred substrate. If the arboreal pathways connecting sections within their home ranges continue to disappear, some areas may become completely inaccessible, as the primates are reluctant to travel long distances on the ground. Indeed, the use of human-made substrates had fatal consequences on 3 occasions during our study. These observations strongly corroborate the assumption that environmental factors associated with living in close proximity to humans directly affect the langurs (Roonwal \& Mohnot 1977).

Hladik (1977) found that, as is typical of colobines, Trachypithecus vetulus mainly fed on mature leaves. Conversely, Dela (2007) showed that T. v. nestor residing in a human-dominated landscape subsisted on fruit from human-cultivated species. She found that jak fruit was a key food source, and this also featured in our top tree species in both home ranges. Paradoxically, it may be that T. v. nestor is able to survive in a human-dominated habitat because they are living commensally with humans (Goldstein \& Richard 1989, Young \& Isbell 1994). As natural forests are cleared and replaced with trees primarily for human consumption and/or use (e.g. jak fruit, mango, rambutan, rubber), these new plantations could potentially provide higher densities of food resources than natural forests. We concur with Dela (2007) that the repercussions of the long-term physiological affects of this unusual diet need to be examined.

Home range sizes vary greatly both within and between colobine species, a fact that can be accredited in part to ecological variability (Newton 1987). The majority of Asian colobines have home ranges $<100$ ha, but some are known to reach 1000 ha (Bennett \& 
Davies 1994, Kirkpatrick et al. 1997). Home-range sizes within Trachypithecus vetulus spp. also vary (Roonwal \& Mohnot 1977, Bennett \& Davies 1994). Our 2 home-range estimates are consistent with previous findings for $T$. vetulus, where 20 groups were investigated, yielding home ranges from 0.9 to 14.9 ha (Rudran 1973b, Dela 2004). Undeniably, the short nature of our study may have resulted in observation of only partial home ranges. For example, as food resources are usually unevenly distributed and seasonal, some areas of the home range may not be used year round ( $\mathrm{Li}$ et al. 2000, Li \& Rogers 2005). In Talangama, however, the surrounding lake and paddy fields, together with forest clearance for new houses starkly restrict the available space for $T$. $V$. nestor. Indeed, langurs never used some areas within their home ranges which had been cleared for building of houses, grazing, and roads, meaning actual functional home ranges may be even smaller than reported here. In our opinion, unless langurs crossed these large barriers or substantially overlapped their ranges, available space simply did not allow for larger ranges; there is nowhere else for them to go.

The stability of an ecosystem can ultimately indicate the future survival prospects for its resident primates (Tabarelli et al. 1997). For the 2 home ranges in Talangama, we found that Home Range B contained higher species richness and diversity. Large areas in Home Range A had been cleared for housing, roads and grazing, and its housing density was already twice that of Home Range B. Due to its close proximity to Colombo, real-estate value in the Talangama area is high, and development is already underway in Home Range B. Cultivated Arctocarpus heterophyllus is a key food source for the langurs and is also dominant in both home ranges. The large size of these trees is also a sign of their maturity (Woinarski et al. 1997). More mature trees can potentially offer a greater yield of fruit, thicker branches for resting, protection from predators and shelter from harsh weather (Huang et al. 2003). In this fragmented landscape, the langurs apparently rely on $A$. heteropyllus for these attributes. Ultimately, their survival is entirely dependent on the humans who maintain these important fruit trees.

We clearly demonstrate that commensalism with humans has numerous direct impacts on western purple-faced langurs, including use of human-made substrates, increased dietary flexibility and an increased tolerance towards humans. The ability to survive commensally in small ranges, supplemented almost wholly by human food trees, is a promising aspect for their short-term survival. Over time, however, there will be a limit to the amount of habitat degradation that Trachypithecus vetulus nestor can tolerate (cf. Siex 2005). The progressive urbanisation occurring throughout the range of $T$. V. nestor means that home gardens are shrinking and so too is langur habitat, forcing the langurs to use less desirable substrates that can lead to fatalities. Distances between habitat patches are lengthening and groups are becoming increasingly separated (Parker et al. 2008), a trend that will inevitably raise questions concerning gene flow and population viability. Implementation of forest corridors, rope bridges, living fences and forestregeneration programmes linking populations are essential to the survival of $T$. V. nestor. Furthermore, human-wildlife conflict will no doubt worsen as langur habitat continues to diminish or as people simply become less tolerant of these animals (Nijman \& Nekaris 2010). Buddhist beliefs have, in the past, shielded T. v. nestor to some extent from persecution (Rudran 2007, Wolfe \& Fuentes 2007), but recent reports in Sri Lanka suggest a shift in human tolerance (Dela 2004, Nahallage et al. 2008). This shift may be exacerbated by the fact that $T$. $V$. nestor is showing greater tolerance towards humans, thus making individuals of the species easy targets for catapults and rifles (Eschmann et al. 2008). It is evident that a broader understanding of the complex interactions that take place between humans and primates living in sympatry is of paramount importance to the survival of T. v. nestor.

Acknowledgements. We thank G. de Silva Wijeyeratne and the staff of Jetwing Hotels and Jetwings Eco Holidays for support under the Jetwing Research Initiative for organising the logistics of this study. K. Conniff and family, So. Harantika, Sa. Harantika, Gayani, and Malene provided assistance and/or accommodation in the field. We thank the villagers of Hokandara-South who allowed us access to their land to observe the monkeys. Two anonymous reviewers, S. K. Bearder, G. Donati, M. McLennan, and V. Nijman provided valuable comments on the manuscript. The research was funded by the People's Trust for Endangered Species, Oxford Brookes University Primate Conservation Programme, Reinvention Undergraduate Research Scholarship Scheme, and Jetwing Eco Holidays Research Initiative.

\section{LITERATURE CITED}

Ashton M, Gunatilleke S, de Zoysa N, Dassanayake MD, Gunatilleke N, Wijesundera S (1997) A field guide to the common trees and shrubs of Sri Lanka. WHT Publications, Colombo

Ashton MS, Gunatilleke CVS, Singhakumara BMP, Gunatilleke IAUN (2001) Restoration pathways for rain forest in Sri Lanka: a review of concepts and models. For Ecol Manag 154:409-430

Bennett EL, Davies AG (1994) The ecology of Asian colobines. In: Davies AG, Oates JF (eds) Colobine monkeys: their ecology, behaviour and evolution. Cambridge University Press, Cambridge, p 129-172

Bishop N, Hrdy SB, Teas J, Moore J (1981) Measures of human influence in habitats of South Asian monkeys. Int J Primatol 2:153-167 
Boulton AM, Horrocks JA, Baulu J (1996) The Barbados vervet monkey (Cercopithecus aethiops sabaens): changes in population size and crop damage, 1980-1994. Int J Primatol 17:831-844

Chhangani AK, Mohnot SM (2004) Crop raiding by Hanuman langur Semnopithecus entellus in and around Aravallis (India) and its management. Primate Rep 69: 35-47

Colquhoun I (2005) Primates in the forest: Sakalava ethnoprimatology and synecological relations with black lemurs at Ambato Massif, Madagascar. In Paterson JD, Wallis J (eds) Commensalism and conflict: the human-primate interface. The American Society of Primatologists, Norman, OK, p 91-117

Cowlishaw G, Dunbar R (2000) Primate conservation biology. The University of Chicago Press, London

Dela J (2004) Protecting the endemic purple-faced leaf monkey. Loris 23:14-22

Dela J (2007) Seasonal food use strategies of Semnopithecus vetulus nestor, at Panadura and Piliyandala, Sri Lanka. Int J Primatol 28:607-626

Eschmann C, Moore R, Nekaris KAI (2008) Calling patterns of western purple-faced langurs (Mammalia: Primates: Cercopithecidea: Trachypithecus vetulus nestor) in a degraded human landscape in Sri Lanka. Contrib Zool 77: 57-65

Fowler J, Cohen L, Jarvis P (1998) Practical statistics for field biology, 2nd edn. John Wiley \& Sons, New York, NY

FRGI (2004) Falling rain genomics incorporated, Sri Lanka. Accessed 01 June 2010, available at: www.fallingrain. com/world/CE/36/Talangama_South.html

Ganzhorn JU (2003) Habitat description and phenology. In: Setchell JM, Curtis DJ (eds) Field and laboratory methods in primatology: a practical guide. Cambridge University Press, Cambridge, p 40-56

Goldstein SJ, Richard AF (1989) Ecology of rhesus macaques (Macaca mulatta) in northwest Pakistan. Int J Primatol 10: 531-567

Gusset M, Swarner MJ, Mponwane L, Keletile K, McNutt JW (2009) Human-wildlife conflict in northern Botswana: livestock predation by endangered African wild dog Lycaon pictus and other carnivores. Oryx 43:67-72

Hanna KC, Culpepper RB (1998) GIS in site design. New tools for design professionals. Wiley, New York, NY

Hernandez A (2008) Cherry removal by seed-dispersing mammals: mutualism through commensal association with frugivorous birds. Pol J Ecol 56:127-138

Hladik CM (1977) A comparative study of the feeding strategies of two sympatric species of leaf monkeys: Presbytis senex and Presbytis entellus. In: Clutton-Brock TH (ed) Primate ecology: studies of feeding and ranging behavior in lemurs, monkeys, and apes. Academic Press, London, p 323-353

Hochegger K (1998) Farming like the forest: traditional home garden systems in Sri Lanka. Tropical Agroecology 191, Margraf Verlag, Weikersheim

Huang C, Wei F, Li M, Li Y, Sun R (2003) Sleeping cave selection, activity pattern and time budget of white-headed langurs. Int J Primatol 24:813-824

Huang C, Li Y, Zhou Q, Feng Y, Chen Z, Yu H, Wu Z (2008) Karst habitat fragmentation and the conservation of the white-headed langur (Trachypithecus leucocephalus) in China. Primate Conserv 23:133-139

IUCN (International Union for Conservation of Nature) (2008) IUCN red list 2008: a new assessment of Endangered primates. IUCN, Gland, accessed 01 June 2010, available at: www.primate-sg.org/redlist08.htm
Kirkpatrick RC (2007) The Asian colobines. In: Campbell CJ, Fuentes A, MacKinnon KC, Panger M, Bearder SK (eds) Primates in perspective. Oxford University Press, Oxford, p 186-200

Kumar A, Konstant WR, Mittermeier RA (1999) Western Ghats and Sri Lanka. In: Mittermeier RA, Myers N, Gill PR, Mittermeier CG (eds) Hotspots: earth's biologically richest and most endangered terrestrial ecoregions. CEMEX, Conservation International and Agrupacion Sierra Madre, Monterrey, p 353-364

Li Z, Rogers M (2005) Habitat quality and range use of whiteheaded langurs in Fusui, China. Folia Primatol (Basel) 76: 185-195

> Li B, Chen C, Ji W, Ren B (2000) Seasonal home range changes of the Sichuan snub-nosed monkey (Rhinopithecus roxellana) in the Qinling mountains of China. Folia Primatol (Basel) 71:375-386

> Mandujano S, Escobedo-Morales LA, Palacios-Silva R (2004) Movements of Alouatta palliata among forest fragments in Los Tuxtlas, Mexico. Neotrop Primates 12:126-131

Manley GH (1986) Through the territorial barrier: harem accretion in Presbytis senex. In: Else JG, Lee PC (eds) Primate ontogeny, cognition, and social behaviour. Cambridge University Press, Cambridge, p 363-371

> Manor R, Cohen O, Saltz D (2008) Community homogenization and the invasiveness of commensal species in Mediterranean afforested landscapes. Biol Invasions 10:507-515

Marsh LK (ed) (2003) The nature of fragmentation. In: Primates in fragments. Kluwer Academic/Plenum Publishers, London, p 1-10

Mueller-Dombois D, Ellenberg H (1974) Aims and methods of vegetation ecology. John Wiley \& Sons, New York, NY

Nadler T, Thanh VN, Steicher U (2007) Conservation status of Vietnamese primates. Vietn J Primatol 1:7-26

Nahallage CAD, Huffman MA, Kuruppu N, Weerasingha T (2008) Diurnal primates in Sri Lanka and people's perception of them. Primate Conserv 23:81-87

Nekaris KAI, de Silva Wijeyeratne G (2009) The primates of Sri Lanka. Lankan Tourism Promotion Bureau, Colombo

Nekaris KAI, Nijman V (2008) Attention for Sri Lankan monkey paints a bleak picture yet gives a glimmer of hope. Oryx 42:487-488

Newton PN (1987) Social organization of forest Hanuman langurs (Presbytis entellus). Int J Primatol 8:199-232

Newton P, Dunbar RIM (1994) Colobine monkey society. In: Davies AG, Oates JF (eds) Colobine monkeys: their ecology, behaviour and evolution. Cambridge University Press, Cambridge, p 311-346

Nijman V, Nekaris KAI (2009) The primates of Sri Lanka. Sri Lankan Tourism Promotion Bureau, Colombo

Osborne FV, Parker GE (2003) Towards an integrated approach for reducing the conflict between elephants and people: a review of current research. Oryx 37:80-84

Parker L, Nijman V, Nekaris KAI (2008) When there is no forest left: fragmentation, local extinction and small population sizes in the Sri Lankan western purple-faced langur. Endang Species Res 5:29-36

Patterson J (2001) Primate behavior: an exercise workbook. Waveland, Prospect Heights, IL

Rajpurohit LS, Sommer V, Mohnot SM (1995) Wanderers between harems and bachelor bands: male Hanuman langurs (Presbytis entellus) at Jodhpur in Rajasthan. Behaviour 132:255-299

Riley EP (2006) Ethnoprimatology: toward reconciliation of biological and cultural anthropology. Ecol Environ Anthropol 2:1-10

Roonwal ML, Mohnot SM (1977) Primates of South Asia: 
ecology, sociobiology and behaviour. Harvard University Press, Cambridge, MA

Rudran R (1973a) The reproductive cycles of two subspecies of purple-faced langurs (Presbytis senex) with relation to environmental factors. Folia Primatol 19:41-60

Rudran R (1973b) Adult male replacement in one-male troops of purple-faced langurs (Presbytis senex senex) and its effect on population structure. Folia Primatol 19:166-192

Rudran R (2007) A survey of Sri Lanka's endangered and endemic western purple-faced langur (Trachypithecus vetulus nestor). Primate Conserv 22:139-144

Rudran R, Weerakoon K, Wanasinghe A (2009) Western purple-faced langur Trachypithecus (Semnopithecus) vetulus nestor Bennett, 1833, Sri Lanka (2004, 2006, 2008). In: Mittermeier RA, Wallis J, Rylands AB, Ganzhorn JU, and others (eds). Primates in peril: the world's 25 most endangered primates 2008-2010. IUCN/SSC PSG, IPS, CI, Arlington, VA, p 53-55

Siex KS (2005) Habitat destruction, population compression and overbrowsing by the Zanzibar red colobus monkey (Procolobus kirkii). In: Paterson JD, Wallis J (eds) Commensalism and conflict: the human-primate interface. The American Society of Primatologists, Norman, OK, p 294-337

Siex KS, Struhsaker TT (1999) Colobus monkeys and coconuts: a study of perceived human-wildlife conflicts. J Appl Ecol 36:1009-1020

Singh M, Rao NR (2004) Population dynamics and conservation of commensal bonnet macaques. Int J Primatol 25: 847-859

Sponsel LE, Ruttanadakul N, Natadecha-Sponsel P (2002) Monkey business? The conservation implications of macaque ethnoprimatology in Southern Thailand. In: Fuentes A, Wolfe LD (eds) Primates face to face: the con-

Editorial responsibility: Christoph Schwitzer, Bristol, UK servation implications of human-nonhuman primate interconnections. Cambridge University Press, Cambridge, p 28-309

Stengel C, Priston N, Nekaris KAI (2009) Predicting primate distributions in Sri Lanka's forest fragments: using ecological niche modelling to set conservation priorities. Folia Primatol 80:173

Sterck EHM, van Hooff JARAM (2000) The number of males in langur groups: monopolisability of females or demographic processes? In: Kappeler PM (ed) Primate males: causes and consequences of variation in group composition. Cambridge University Press, Cambridge, p 120-129

Tabarelli M, Mantovani W, Zimmerman B, Peres CA (1997) Effects of habitat fragmentation on plant guild structure in the montane Atlantic forest of southeastern Brazil. Biol Conserv 91:119-127

Turner IM (1996) Species loss in fragments of tropical rain forest: a review of the evidence. J Appl Ecol 33:200-209

Waite T, Chhangani AK, Campbell LG, Rajpurohit LS, Mohnot SM (2007) Sanctuary in the city: urban monkeys buffered against catastrophic die-off during ENSOrelated drought. EcoHealth 4:278-286

Woinarski J, Recher H, Majer J (1997) Vertebrates of eucalypt formations. In: Williams J, Woinarski J (eds) Eucalypt ecology: individuals to ecosystems. Cambridge University Press, Cambridge, p 303-341

Wolfe LD, Fuentes A (2007) Ethnoprimatology: contextualising human and nonhuman primate interactions. In: Campbell CJ, Fuentes A, MacKinnon KC, Panger M, Bearder SK (eds) Primates in perspective. Oxford University Press, Oxford, p 691-702

Young TP, Isbell LA (1994) Minimum group size and other conservation lessons exemplified by a declining primate population. Biol Conserv 68:129-134

Submitted: June 16, 2009; Accepted: July 30, 2010

Proofs received from author(s): September 7, 2010 